\section{An assessment of the small hydro potential in Sri Lanka}

\section{Sunith Fernando}

Resource Management Associates (Pvt) Ltd., No. 3, Charles Terrace, Colombo 3, Sri Lanka

\section{Introduction}

The south-western quarter of Sri Lanka is characterised by persistent rainfall that lasts for nearly nine months in some parts of the hill country. The mean annual rainfall varies from about $5500 \mathrm{~mm}$, in the wettest parts of the island, to around $3000 \mathrm{~mm}$ in most parts of the central and south-west mountain ranges. Geologically, these mountain ranges are characterised by steeply dissected hilly and rolling terrain. This geo-climatic combination causes a large number of streams to radiate from the upper reaches of mountains. They merge downstream to form some of Sri Lanka's major rivers, such as Kelani Ganga, Mahaweli Ganga and Kalu Ganga. Small streams in the upper catchments as well as major rivers offer considerable potential to generate hydroelectric power.

Colonial planters, who established large-scale plantations in the south-western quarter of the island, were the first to tap hydro power in small streams to generate electricity and motive power for their plantation industries. It is estimated that around 500 such micro-hydro plants had been in operation in the early part of the 20th century. This paper presents a preliminary assessment of the small hydro potential in Sri Lanka, focussing largely on the plantation sector. It is based on a two-year research study conducted by the Sri Lanka Country Office of the Intermediate Technology Development Group.

\section{Methodology and scope}

The initial phase of the study was collection of information on old small hydro sites in Sri Lanka. Three sources of information were used for this purpose. They are: (a) Sri Lanka Mini Hydro Rehabilitation Project - Salford Civil Engineering Ltd. with Binnie \& Partners - 1986 (referred to hereafter as ODA study); (b) Feasibility Study for the Rehabilitation of Mini Hydro Stations, Cansult Ltd, Canada - 1984 (referred to heareafter as Cansult study) and (c) the database of Gilbert Gilkes and Gordon on turbines supplied to Ceylon. The first two studies addressed the feasibility of rehabilitating abandoned microhydro plants in the plantation sector. The ODA study [ODA, 1986] was very much a feasibility report concerning eight selected small hydro sites and revealed very little about hundreds of other old hydro sites. The Cansult study [Cansult, 1984] has examined about forty sites for redevelopment and presents the technical details for nineteen sites. The database of Gilbert Gilkes and Gordon [GGG, undated] provided the most useful information about old micro-hydro sites in Sri Lanka.

On the basis of this information, old hydro sites, either abandoned or operational, were identified and located on the relevant one-inch (i.e., scale of 1 inch $(2.54 \mathrm{~cm})$ to 1 mile $(1.61 \mathrm{~km}))$ topographical map. Each site was then visited and the status of the existing hydro scheme was examined and the following data were recorded.

- Operational status, i.e., abandoned, not in operation or in operation.

- Location (latitude and longitude) and length of the weir.

- Channel cross-section (depth and width) and the length (length is only an estimate made while walking along the channel path).

- Dimensions of the forebay tank.

- Diameter and length of the penstock. Length was mostly estimated on the basis of the direct distance (measured using the distance measuring instrument Ranger 400) between the powerhouse and forebay.

- Type of the turbine and its design flow and head.

- Generator rating.

- Exploitable downstream head.

In addition to the above, investigations were also made about other potential sites in the area. In such sites, the head was estimated using contour data given in the topographical map, and physical measurements were limited only to sites which allowed the use of Ranger 400, i.e., where visibility was clear and the distance was less than $400 \mathrm{~m}$. Identification of potential sites was usually done before planning the site visits. As the contour interval of the map is only $30 \mathrm{~m}$, new sites having less than $30 \mathrm{~m}$ head were skipped to a large extent in the survey.

In respect of both the existing schemes and new ones, the exploitable power potential was estimated on the basis of the average daily flow (ADF) and not the optimum design flow for the site, which will have to be determined through a detailed design analysis.

\section{Data analysis}

The study covered 292 sites covering both estate sites and non-estate sites. Streams in some of the sites, particularly where very small capacity hydro plants were in use, were no longer in existence. Thus, the total number of sites studied and entered into the database is 276 . These could be categorised as:

- Old estate sites. These are sites where there are or had been hydro plants in the past. The current status of the hydro plants in this category is defined as:

- abandoned, i.e., either no trace of the scheme is visible or some parts of the scheme are available but in a dilapidated state;

- not in operation, i.e., the scheme is mostly in place but not being used - the scheme could be rehabilitated if necessary; or

- in operation, i.e., the plant was in operation or under repairs at the time of visit.

- New estate sites. A new location found within the boundaries of the particular estate.

- Non-estate sites. A site located outside an estate, mostly on state land.

Of the 276 sites surveyed, data on the exploitable small hydro potential is available only for 257 sites. Hence, further analysis was confined to the 257 sites. The distribution of 
Table 1. Distribution of surveyed sites by status of site

\begin{tabular}{|l|c|c|}
\hline Site classification & $\begin{array}{c}\text { Number of } \\
\text { sites }\end{array}$ & $\begin{array}{c}\text { \% } \\
\text { composition }\end{array}$ \\
\hline Old estate sites & 137 & 53.3 \\
\hline New estate sites & 71 & 27.6 \\
\hline Non-estate sites & 49 & 19.1 \\
\hline Total & 257 & 100.0 \\
\hline
\end{tabular}

Table 2. Number of sites, utilised capacity and exploitable potential in old estate sites

\begin{tabular}{|l|c|c|c|}
\hline Classification of sites & $\begin{array}{c}\text { Number } \\
\text { of sites }\end{array}$ & $\begin{array}{c}\text { Utilised } \\
\text { capacity (kW) }\end{array}$ & $\begin{array}{c}\text { Exploitable } \\
\text { potential }(\mathbf{k W})\end{array}$ \\
\hline In operation & 49 & 3,343 & 10,367 \\
\hline Not in operation & 14 & 544 & 2,555 \\
\hline Abandoned & 74 & 2,228 & 10,746 \\
\hline Total & 137 & 6,115 & 23,668 \\
\hline
\end{tabular}

Table 3. Distribution of new estate sites by district

\begin{tabular}{|l|r|r|c|}
\hline District & $\begin{array}{c}\text { Number } \\
\text { of sites }\end{array}$ & $\begin{array}{c}\text { Exploitable } \\
\text { potential } \\
(\mathbf{k W})\end{array}$ & $\begin{array}{c}\text { Average site } \\
\text { potential } \\
(\mathbf{k W})\end{array}$ \\
\hline Nuwara Eliya & 37 & 12,496 & 338 \\
\hline Kegalle & 7 & 2,888 & 412 \\
\hline Ratnapura & 8 & 2,457 & 307 \\
\hline Kandy & 9 & 1,697 & 188 \\
\hline Badulla & 9 & 1,093 & 121 \\
\hline Galle & 1 & 92 & 92 \\
\hline Total & 71 & 20,723 & \\
\hline
\end{tabular}

Table 4. Distribution of non-estate sites by district

\begin{tabular}{|l|r|r|c|}
\hline District & No. of sites & $\begin{array}{c}\text { Capacity } \\
\text { (kW) }\end{array}$ & $\begin{array}{c}\text { \% } \\
\text { composition } \\
\text { of capacity }\end{array}$ \\
\hline Ratnapura & 22 & 26,800 & 51 \\
\hline Kegalle & 11 & 9,972 & 19 \\
\hline Kandy & 5 & 6,850 & 13 \\
\hline Nuwara Eliya & 8 & 5,847 & 10 \\
\hline Badulla & 1 & 3,067 & 6 \\
\hline Matara & 2 & 479 & 1 \\
\hline Total & 47 & 53,016 & 100 \\
\hline
\end{tabular}

the surveyed sites among the three categories is presented in Table 1.

\subsection{Old estate hydro sites}

Of the total number of surveyed sites $53.3 \%$ (137 sites) fall into the category of old estate sites. The combined installed capacity at these sites is around $6115 \mathrm{~kW}$ and they include sites belonging to the three classifications abandoned, not in operation and in operation. The distribution of capacity, both utilised and exploitable, among these three types of sites is presented in Table 2. The analysis shows that the capacity of hydro plants currently in operation could be increased from the present installed capacity of $3,343 \mathrm{~kW}$ to over $10,000 \mathrm{~kW}$ while the combined capacity of sites (of all three classifications) could increase nearly four-fold.

The distribution of these sites by district is shown in Figure 1, according to which the highest number of old sites are found in Nuwara Eliya district (42\%) followed by Kandy (21\%) and Ratnapura (12\%).

\subsection{New estate sites}

During visits to estates having abandoned or operational hydro plants, further investigations were conducted to locate new sites within the same estate. A few of the new estate sites include those which have not had used hydro-power in the past. The distribution of new estate sites by district is presented in Table 3, which shows that the highest exploitable potential of nearly $12,500 \mathrm{~kW}$ is found in Nuwara Eliya district. The highest average site potential of $412 \mathrm{~kW}$ is found in Kegalle district. The total exploitable potential at new sites in the estate sector is over $20,000 \mathrm{~kW}$.

\subsection{Non-estate sites}

Distribution of non-estate sites by district is presented in Table 4, according to which the highest potential of $26,800 \mathrm{~kW}$ is found in Ratnapura district, followed by Kegalle district with 9,972 kW. Almost all non-estate sites are found on state land, often interspersed with village settlements, some bordering forest reserves. Therefore, development of these sites is likely to face social and environmental issues to some extent.

\section{Total potential of the surveyed sites}

The total estimated small hydro potential at the 257 surveyed sites is $97.4 \mathrm{MW}$ (see Table 5), which is distributed among the three site categories as: $24.4 \%$ in old estate sites, $21.2 \%$ in new estate sites and the remaining $54.4 \%$ in non-estate sites. The highest potential encountered in the study is $5,192 \mathrm{~kW}$ on Kuru Ganga while the lowest capacity of $5 \mathrm{~kW}$ was found in one of the old estate sites, Maria division of Waltrim Estate. Capacity utilised in old estate sites is estimated as 6.1 MW.

Distribution of all sites by the estimated exploitable small hydro potential is presented in Figures 2 and 3 for two ranges of capacity, viz., 0-500 kW and 500-4000 kW. According to these, in $81 \%$ (209 sites) of the surveyed sites, the potential lies in the range $0-500 \mathrm{~kW}$. Within this range, $22 \%$ of sites have a capacity of less than $50 \mathrm{~kW}$ and $25 \%$ lie between $50 \mathrm{~kW}$ and $100 \mathrm{~kW}$. In the range of $500 \mathrm{~kW}$ to $4000 \mathrm{~kW}$ (48 sites) nearly $70 \%$ of sites have capacities between $500 \mathrm{~kW}$ and $1500 \mathrm{~kW}$. 


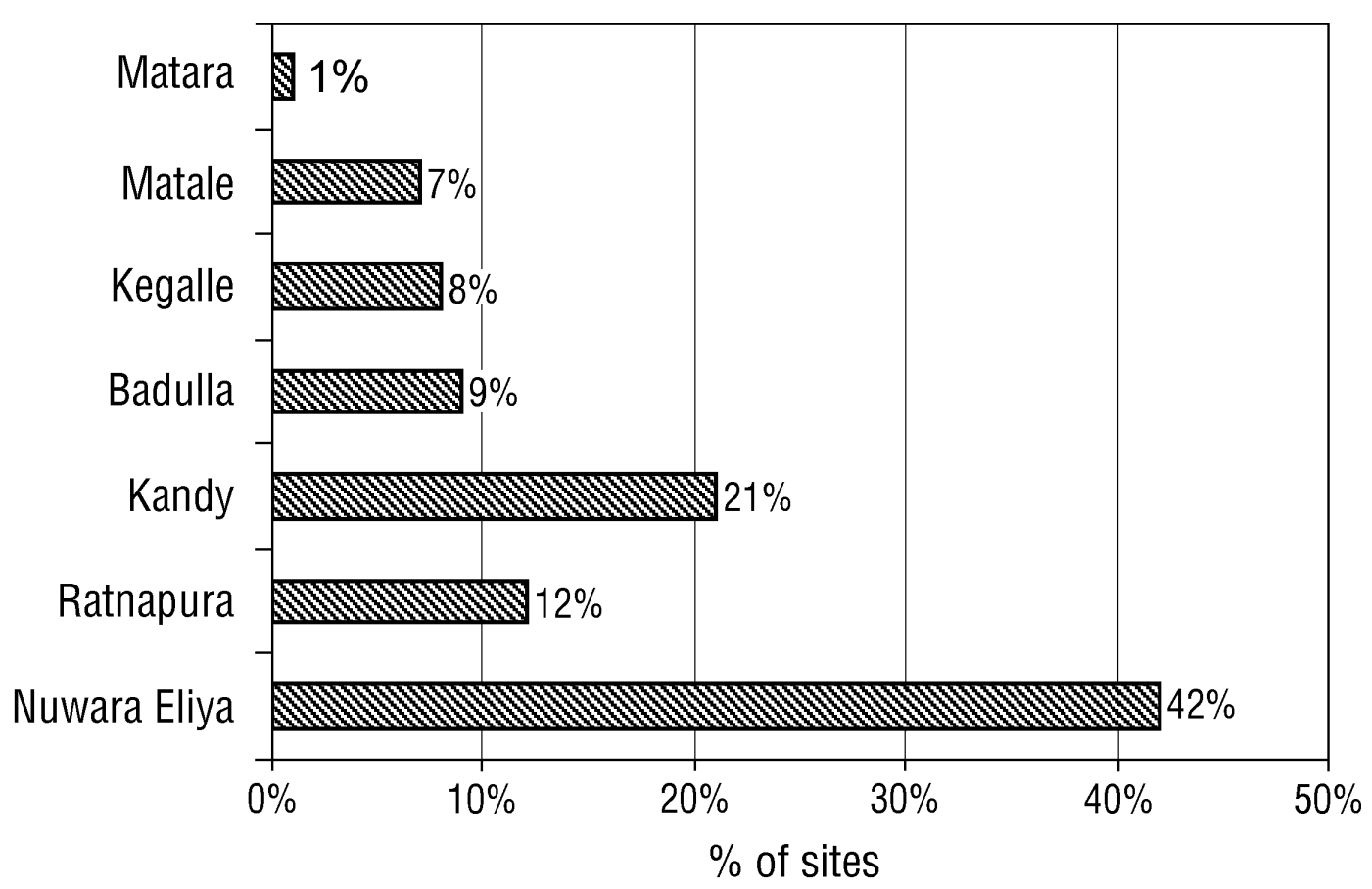

Figure 1. Distribution of old hydro sites by district

Table 5. Distribution of all sites by classification and capacity

\begin{tabular}{|c|c|c|c|c|c|c|}
\hline \multirow[t]{2}{*}{ Site classification } & \multirow{2}{*}{$\begin{array}{c}\text { Number } \\
\text { of sites }\end{array}$} & \multirow{2}{*}{$\begin{array}{c}\text { Utilised } \\
\text { potential (MW) }\end{array}$} & \multicolumn{2}{|c|}{ Exploitable potential } & \multirow{2}{*}{$\begin{array}{l}\text { Highest site } \\
\text { capacity }(\mathrm{kW})\end{array}$} & \multirow{2}{*}{$\begin{array}{l}\text { Lowest site } \\
\text { capacity }(\mathrm{kW})\end{array}$} \\
\hline & & & MW & $\%$ of the total & & \\
\hline Old estate sites & 137 & 6.1 & 23.668 & 24.4 & 1,665 & 5 \\
\hline New estate sites & 71 & - & 20.723 & 21.2 & 1,127 & 8 \\
\hline Non-estate sites & 49 & - & 53.016 & 54.4 & 5,192 & 44 \\
\hline Total & 257 & & 97.407 & 100 & & \\
\hline
\end{tabular}

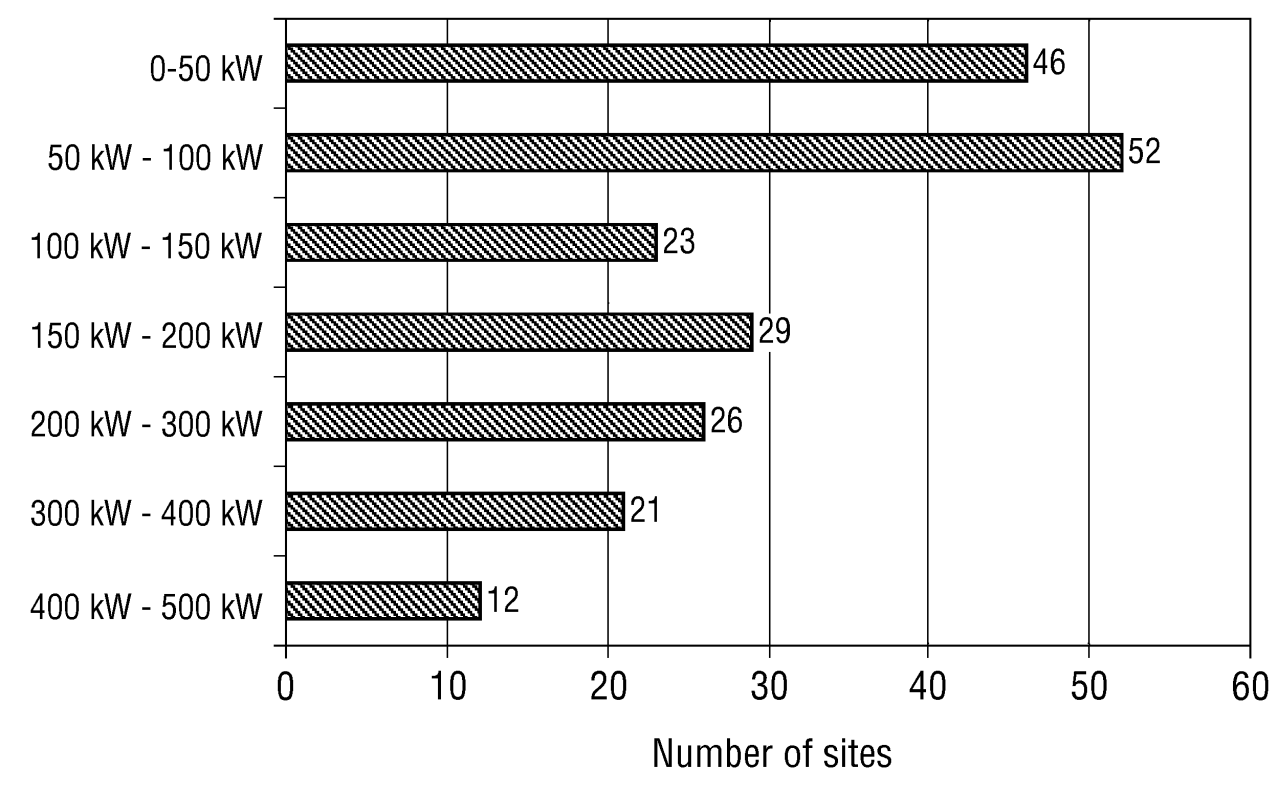

Figure 2. Distribution of exploitable power - site capacity $<500 \mathrm{~kW}$ 


\section{Letters}

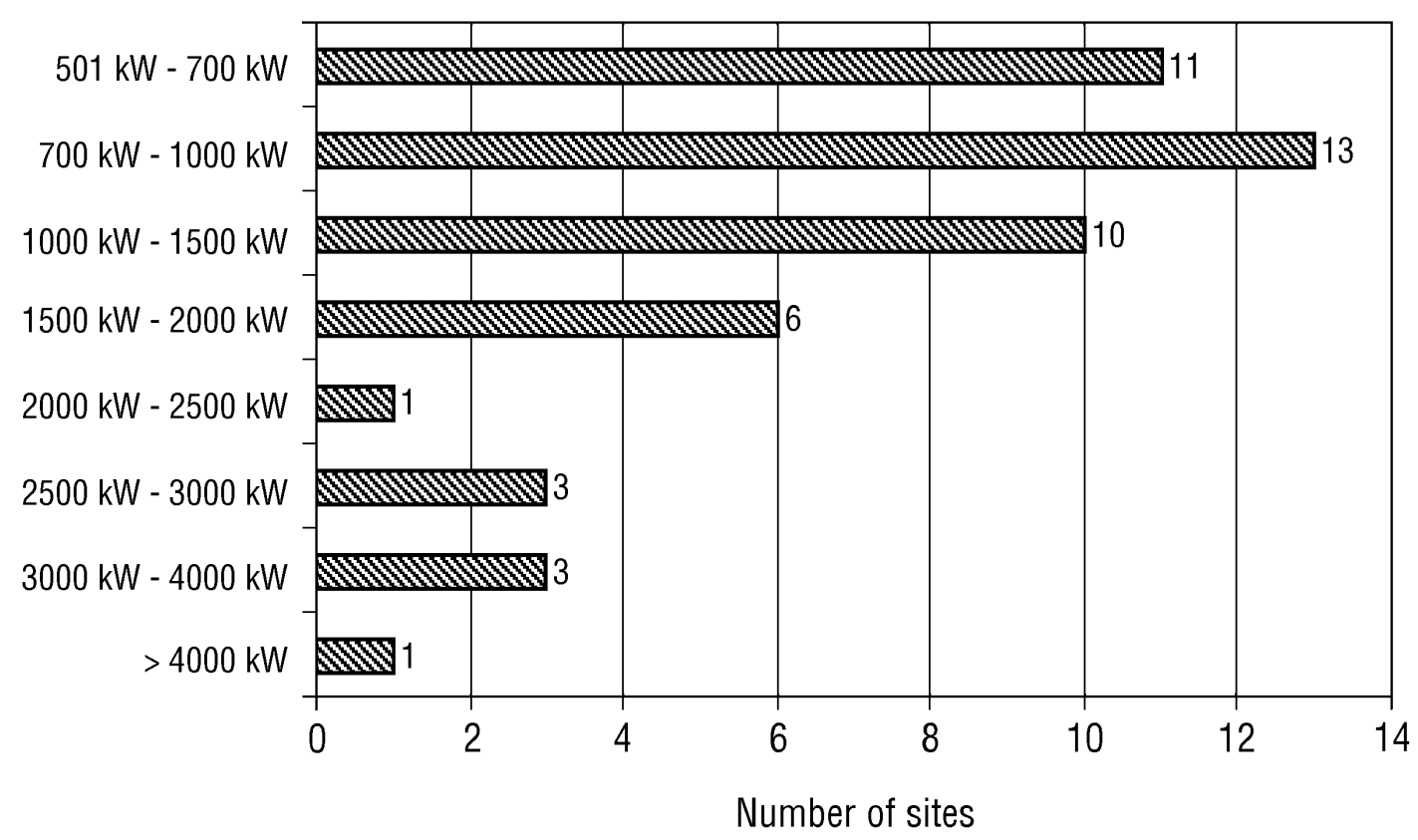

Figure 3. Distribution of exploitable power - site capacity $>500 \mathrm{~kW}$

\section{Acknowledgement}

I would like to extend my grateful appreciation to the Royal Norwegian Embassy in Sri Lanka for providing financial assistance to this study, which I carried out on behalf of the Intermediate Technology Development Group (ITDG). I thank Lahiru Perera, Regional Director (South Asia) of ITDG, for giving me the opportunity to engage myself in this interesting study.

Visiting over 200 hydro sites and conducting field surveys is not a task that I could have handled alone and several of my friends, who are engaged in work on small hydro power, helped me with this work. In particular, I wish to thank Priyantha Hettiarachchi, Lionel Fernando, Kingsley Jayawardena, L. Aiyadasa, and Bernard Perera for helping me with this work. I thank Rohitha Ananda for helping me with the development of the computerised database on small hydro sites.

\section{References}

Overseas Development Administration (ODA), 1986. Sri Lanka Mini Hydro Rehabilitation Project conducted by Salford Civil Engineering Ltd. with Binnie \& Partners, carried out under assignment by the Overseas Development Administration, UK.

Cansult, 1984. Feasibility Study for the Rehabilitation of Mini Hydro Stations, carried out by Cansult Ltd.

GGG, undated. Gilbert Gilkes and Gordon in Sri Lanka - List of hydro plants supplied to Ceylon by Gilbert Gilkes \& Co. Ltd. from 1887 to 1960. 